\title{
SEÑOR, ¿QUÉ QUIERES QUE
HAGA?
}

SERIE: DESTINO DE GLORIA

Heidinger Zeballos, Edward

División Sudamericana de la

Iglesia Adventista del Séptimo Día edward.heidinger@adventistas.org.br

Fecha de recepción: Agosto 2012

Fecha de aceptación y versión final: Septiembre 2012

Texto base: Hechos 22:1-10

Propósito General: Motivación

Palabra clave: Preguntas

\section{Introducción}

- Saludo: Buenos días, jfeliz sábado!

- Frase alusiva: En esta serie de sermones "Destino de gloria" vamos a estudiar algunos episodios en la vida del apóstol Pablo y algunas de sus enseñanzas registradas en sus cartas.

- Disparador: Existen preguntas superficiales que las planteamos para buscar información básica o para generar un diálogo.

- Texto: El texto en el que se basa el sermón en esta oportunidad es Hechos 22:1-10

- Proposición: Tú tienes un destino de gloria porque Dios tiene un plan para tu vida, pero para 
que su plan se haga realidad en ti, debes dejar tu camino para seguir el Camino.

- Pregunta de transición: ¿Por qué afirmamos que tienes un destino de gloria?

- Frase de transición: Porque todo hijo de Dios pasa por tres etapas en su caminar en este mundo, ellas son las siguientes:

\section{Primera etapa: el camino y el Camino}

Lección: Existe total diferencia entre estar en el Camino y estar en el camino. El camino con minúscula es la simple ruta que decidí andar por mi cuenta, pero el Camino con mayúscula es el que Dios tiene preparado para mí, es la ruta de aspiraciones, desafíos y victorias mayores que Dios planificó para mi vida.

Texto prueba: Hechos 22:1-2. Pablo siendo ya de edad avanzada narra en este pasaje un episodio trascendental que le aconteció mientras era joven, y de este pasaje de su vida se puede aprender lo siguiente:

a) ¿Quién era Pablo? Leer Hechos 22:3: Él era un judío, celoso guardador de la ley.

b) Leer Hechos 22:4-5

c) ¿La letra inicial de la palabra camino está en minúscula o en mayúscula?

d) En aquel tiempo a los primeros cristianos antes que se llamen cristianos se les llamaba los del Camino, por eso en la Biblia aparece con C mayúscula.

e) Se puede resumir esta primera parte del pasaje bíblico así: Pablo andando en su camino (con minúscula) perseguía a los que estaban en el Camino (con mayúscula). 
f) Pablo creía que estaba en el camino correcto y que los otros estaban totalmente equivocados.

g) En esta vida todos elegimos un camino (minúscula) pero no todos estamos en el Camino (mayúscula).

Ilustración: Cada camino tiene un destino, y alguna vez es probable que nos hayamos encontrado perdidos frente a dos caminos. Al comienzo es poca la diferencia entre un camino y otro, pero con el transcurrir del mismo, la separación se hace más notoria. No hay cosa más frustrante que descubrir que estaba en el camino errado, pero es peor mantenerse toda una vida en ese mismo camino.

Aplicación: El camino tiene que ver no solo con tu carrera o tu religión, tiene que ver con tu vida, con tus decisiones, tus prioridades, tiene que ver con el destino a dónde pretendes llegar:

a) ¿En qué camino estás tú? Algunos van por el camino de la fama, otros del dinero, otros por el camino del placer, y otros por el camino de la mediocridad y del fracaso.

b) La primera etapa en el caminar de la vida, todos la transitamos; sin importar el camino en el que hoy te encuentres, lo que hoy puedo afirmar frente a ti, es que tú estás caminando, y mi deseo es que pases a una segunda etapa en este caminar de la vida.

\section{Segunda etapa: "Señor, ¿qué quieres que haga?"}

Lección: Solo cuando planteas la pregunta correcta al Ser correcto, le concedes a Él la oportuni- 
dad de que te muestre el destino de gloria que te ha preparado.

Texto prueba: Hechos 22:6-10a, meditemos primero en los versos 6-9 (leer nuevamente). Este pasaje nos muestra, que de repente una luz del cielo hizo caer al suelo a Saulo.

a) Era la luz de aquel que se interponía en su camino para mostrarle el Camino verdadero. Era Jesús que había venido al encuentro del perseguidor.

b) Las caídas duelen pero dejan lecciones. Son momentos propicios para descubrir que existe otro camino mejor. Muchas veces es en el dolor cuando nos volvemos más sensibles a la voz de Dios. Es cuando mordemos el polvo de la desesperación que descubrimos que Dios está cerca y que tiene un mejor camino para mí.

c) Postrado en tierra Pablo escucha la voz del Señor Jesús: Soy Jesús a quien tú persigues. Tú tienes tu propio camino pero Yo soy el Camino.

d) Entonces postrado en el suelo, Paulo hace la pregunta que cambiaría el rumbo de su vida. Leer Hechos 22:10

a. ¿Qué haré Señor?

\section{Aplicación:}

a) ¿Señor, qué haré? o ¿Señor, qué quieres que haga? Cuando le planteas esa pregunta a Dios le concedes la oportunidad de que te muestre el destino de gloria que Él te ha preparado. A veces preguntamos: ¿Cuánto voy a ganar? ¿Cuáles son mis derechos? ¿Con quién me casaré? Pero la pregunta más importante que hoy debemos hacernos es: ¿Señor, qué quieres que haga?

b) Pablo estaba diciendo, Señor, hasta aquí he se- 
guido mi propio camino ahora quiero seguir el Camino que tú me has preparado. ¡Muéstrame el Camino!

c) Sin embargo, quedarse con la pregunta y no escuchar la respuesta no es lo ideal, muchos son los que hacen esta pregunta. Muchos llegan a esta segunda etapa en el caminar de la vida, pero hoy quiero que pases a la tercera etapa.

\section{Tercera etapa: "Se tẹ" dirá lo que está ordenado que hagas"}

Lección: Tú tienes un destino de gloria porque Dios tiene un plan para tu vida, pero debes recordar que el éxito no consiste en acumular riquezas o fama, el éxito consiste en descubrir y desarrollar el plan que Dios tiene para ti.

Texto prueba: Hechos 22:10b. Es interesante notar que Jesús no le dijo a Pablo: ve a Damasco entretanto voy pensando qué voy a hacer contigo. Dame un tiempo. Déjame aclarar mis ideas. $\mathrm{O}$ vamos a hacer una comisión para ver tu caso:

a) El verbo traducido como "lo que está ordenado" es el verbo tassō y significa "ubicar en un cierto orden, organizar, asignar un lugar".

La frase "se te dirá lo que está ordenado que hagas" revela que Dios ya tenía algo especial establecido para Pablo, Dios tenía un plan para su vida.

Ilustración: Dios ha planificado tu vida, no vives a la deriva, no siempre cumplimos ese plan y vivimos a la deriva. Pero hoy quiero demostrarte que Dios tiene un plan para tu vida, yo voy comprobando esta afirmación cada día, y tú también puedes hacerlo. 


\section{Aplicación:}

a) Tú tienes un destino de gloria porque Dios tiene un plan para tu vida. Repita conmigo: Tengo un destino de gloria, porque Dios tiene un plan para mi vida.

b) Él planificó algo para ti, aun antes que nacieras.

c) El éxito no consiste en acumular riquezas o fama, el éxito consiste en descubrir y desarrollar el plan que Dios tiene para ti.

d) Te desafío a descubrir en esta serie de sermones los aspectos más resaltantes del plan que Dios tiene para tu vida. Y si ya lo has descubierto, te desafío a renovar tu compromiso de mantenerte en ese $\mathrm{Ca}$ mino, rumbo al destino de gloria que Dios te ha preparado.

\section{Conclusión}

- Recapitulación: La gran pregunta que Pablo le planteó a Dios es: ¿Señor, qué quieres que haga? Entonces descubrió que Dios tenía un plan para su vida, entendió que era mejor dejar su camino para seguir el Camino.

- Aplicación: Tú tienes un destino de gloria porque Dios tiene un plan para tu vida. El éxito consiste en descubrir y desarrollar el plan que Dios tiene para ti.

- Llamado: El llamado que Dios tiene para ti hoy es para plantearle la misma pregunta de Pablo: ¿Señor, qué quieres que haga? ¿Podemos repetirlo? ¿Señor, qué quieres que haga?

- En el próximo sermón analizaremos la respuesta de Dios a esta pregunta. AMÉN. 